\title{
Identification of Component of Technical Assessment and Employability Skills Based on KKNI (Indonesian National Qualification Framework)
}

\author{
Rina Febriana \\ Pendidikan Vokasional dan Keteknikan \\ Universitas Negeri Jakarta \\ Jakarta, Indonesia \\ rinafebriana@unj.ac.id
}

\begin{abstract}
This study aims to identify the components in the assessment model of technical skills and employability skills based on KKNI. The method used is Research and Development ( $R$ \& D) by adopting the model Borg \& Gall. The validation of conceptual and hypothetical models is done through assessment. The effectiveness of the model is done with a limited and expanded trial. The results show that the overall average score is in either category with 3.38 points. This shows that the assessment model of achieving technical skills and employability skills based on KKNI is effective to be used.
\end{abstract}

Keywords—technical skills, employability skills, KKNI

\section{INTRODUCTION}

In order to anticipate changes occurring in a developing and changing society dynamically, vocational education should take care to anticipate these changes. Vocational education has special characteristics, so special handling is required. These characteristics include educational and training-oriented forms of preparation for students to work in certain areas of employment as technical assistants, technicians, or supervisors in the industry. As a process of introducing practical subjects through various educational activities, counseling, education and vocational training, including technology for learners to develop their own capacity and skills (employability skills) [1]. In the process of education and training in schools refers to the understanding of providing subjects with exercises in a light portion of knowledge, vocational skills and technology work-oriented. In this regard, a balanced curriculum is developed. Empirically there is a symptom that the outcomes of the Diploma 3 program have not been as what expected. Many graduate diploma programs have not been accommodated in the world of work. This is indicated by the low percentage of diploma graduates absorbed by employment (72\%). Meanwhile, in the Long Term Development Plan of Manpower and Transmigration 20102025 , stated that the composition of the smallest workforce is at the level of diploma education. In 2008, the labor force was educated by diploma of $2.85 \%$. This figure decreased in 2009 to $2.78 \%$, but increased in 2010 to $2.95 \%$ (RPJP Depnakertrans, 2012). Therefore, the Presidential Regulation of the Republic of Indonesia Year 2012 on the Indonesian National Qualification Framework (KKNI) and PP / 31/2006 on Indonesian National Work Competency Standards as a formulation of job performance covering aspects of knowledge, skills and expertise and work attitude as an effort to achieve the competence of graduates at various levels of Education.

\section{A. Indonesian National Qualification Framework (KKNI)}

The Indonesian National Qualification Framework (KKNI) is a framework of job qualification that matches, equates, integrates, the education and training sectors and work experience in the framework of providing job competence recognition in accordance with job positions in various sectors.

The Indonesian National Qualification Framework (KKNI) consists of 9 (nine) levels of qualification, starting from qualification 1 as the lowest qualification to the 9th qualification as the highest qualification. Qualification level is a nationally agreed-upon level of learning achievement (LO-Learning Outcome), based on the educational outcomes and/or training gained through formal, non-formal, informal, or work experience. The following table is a competency on level 5 for Diploma 3 based on KKNI [2].

TABLE I. QUALIFICATION OF KKNI LEVEL 5

\begin{tabular}{|c|c|c|}
\hline No & Aspect & Description of KKNILevel 5 \\
\hline 1 & Work stalls & $\begin{array}{l}\text { Able to complete wide-ranging work, choose appropriate methods from various options that } \\
\text { have been of have not been standardized by analyzing the data, and able to demonstrate } \\
\text { performance with quality and quantity measurable. }\end{array}$ \\
\hline 2 & Knowledge & $\begin{array}{l}\text { Mastering the theoretical concepts of a paticular field ofluowledge in general, and capable } \\
\text { of formulatimg problem-solving procedural issues }\end{array}$ \\
\hline 3 & Managerial & Able to manage working groups and prepare comprehensive written reports. \\
\hline 4 & $\begin{array}{l}\text { Attitude/ character/ } \\
\text { personality }\end{array}$ & $\begin{array}{l}\text { Responsible for the work itself and can be given responsibility for the achievement of the } \\
\text { work of the group }\end{array}$ \\
\hline
\end{tabular}

\section{B. Technical Skills}

Technical skills are skills in the field of work that include knowledge and skills. Investopedia defines technical skills as a technical work skill that refers to one's talents and skills to perform a particular job or task. In addition, technical skills are also called hard skills as opposed to soft skills namely personality, and character. 
If it is associated with the realm of KKNI, the technical skills are identical with the work skills and knowledge of the work field. Work skills include Capable of completing wideranging work, selecting appropriate methods from a variety of pre-existing and non-standard options by analyzing data, and being able to demonstrate performance with measurable quality and quantity. While working knowledge consists of mastering the theoretical concepts of a particular field of knowledge in general, and able to formulate the solution of procedural problems.

\section{Employability Skills}

In a 2007 publication, Yorke and Knight described a process whereby they attempted to measure what they called student efficacy beliefs [a combination of self-theory and locus of control (LOC)] and their experience of the curriculum in developing their claims of employability. Yorke \& Knight define employability as "a set of achievements, understandings and personal attributes that make individuals more likely to gain employment and be successful in their chosen occupations, which benefit themselves, the workforce, the community and the economy" Achievements, understandings and attributes of one who makes the individual more likely to gain employment and succeed at the choice of work that benefits him, the workforce, society, and the economy [3].

In the employability skills research for the future report it is mentioned that "employability skills are defined as skills required not only to gain employment, but also to progress one's potential and contribute successfully to enterprise strategic directions". Employability skills are defined as the skills required not only to gain employment but also for advancement within the company to increase one's potential and contribute to the strategic direction of the company's success [4]

LSIS states that "Skills for Life and employability should be central to your pre-redundancy offer", skills for living and working should center on the supply of surplus. Furthermore, it was added that "Improved literacy, numeracy, and language skills can have a positive impact on people and their employment prospects. These generic skills can help them to learn new sector-specific and workplace skills", improving reading, counting, language skills can have a positive impact on people and their job prospects [5].

Competence in the world of work is interpreted as a personal aspect (LOMAS) [6]. These personal aspects include nature, motives, value systems, attitudes, knowledge, and skills. The research conducted by Wagiran (2008) on the urgency of graduate competency aspects needed in the industrial world shows that the important aspects of competence are: honesty, work ethic, responsibility, discipline, applying the principles of occupational safety and health, initiative and creativity [7]. It is clear that in terms of competence and skills required, soft skills have a key role in determining the qualifications required by the industry.

This finding is in line with the study conducted by Samani who found the main competency order needed by the industry which includes honesty, discipline, responsibility, cooperation, problem-solving, and occupation [8]. In line with that, a recent study conducted by Andreas in demonstrating that the major competencies expected by the industry include honesty, discipline, communication, cooperation, and mastery of the field of study.

The demand for work skills changes over time. The world of work not only demands to understand and do the job well in the engaged field but also must have the competence and skills that can maintain the continuity of work with better conditions. From some of the above explanations, it can be concluded that Employability Skills is a set of skills that must be owned by someone in an effort to get a job or improve performance in the workplace.

Two key critiques of employability models and research have been argued. First, student perceived control and belief in academic ability have not been considered in recent models of employability [9].

If it is related to the realm of KKNI than technical skills are identical with managerial ability and knowledge of work field and attitude/character/personality. Managerial skills include; ability to manage the working group and prepare a comprehensive written report. While attitude/character/ personality has an indicator such as responsible for the work itself and can be given responsibility for the achievement of group work.

\section{METHOD}

The Research method used in this research is survey method. Survey research is one of the research approaches that is generally used for large and multiple data collection. Survey research is a study that collects information from a sample by asking through questionnaires or interviews describing various aspects of the population [10].

Data collection was done by distributing questionnaires in the form of instruments. Qualitative methods are conducted by structured interviews to get an overview of the learning model that will be applied primarily at the trial time. An instrument questionnaire is used to collect data: a) model validation test by expert; and b) the effectiveness of the use of learning models. The full description of each instrument is as follows:

- List validation. The validation sheet is used to determine the validation of the content and validation of constructs of the development model and assessment instrument. Content validation is intended to measure the accuracy of the theory of development of assessment instruments used in building the instrument development model. Whereas construct validation is intended to measure internal consistency among the learning achievements in the assessment instrument.

- Instrumental Instrument Development Sheet. The observation sheet is used as a guide to assess the learning achievement (CP) on the assessment instrument. It is intended to know the suitability of $\mathrm{CP}$ with parameters and elements of KKNI description.

- Supply of Effectiveness Instrument. Questionnaire response of students and lecturers is an assessment of the assessment instruments used. Constructive assessment of students and lecturers is used as a consideration to revise the assessment instruments developed. 
- The assessment instrument in general is said to be effective if it meets the four indicators of effectiveness, namely: (1) the change of student behavior (2) the teacher's ability to manage the learning, (3) the student and lecturer responses to the developed model, and (4) achievement of student competence

\section{RESUlT AND DISCUSSION}

\section{A. Empirical Data Assesment Instrument}

The assessment instrument that currently applies to the field of expertise has not included the learning achievement aspect based on the description of KKNI. The assessment instrument used only measures the cognitive and practice outcomes

TABLE II. INSTRUMENT AND ASSESMENT TECHNIQUES

\begin{tabular}{|l|l|l|l|}
\hline No & \multicolumn{1}{|c|}{ Aspect } & \multicolumn{1}{|c|}{ Type/Tehcnique } & \multicolumn{1}{|c|}{ Instrument } \\
\hline 1. & Attitude & Observation & $\begin{array}{l}\text { Individual Observation } \\
\text { Sheet \& Discussion } \\
\text { Observation Sheet }\end{array}$ \\
\hline 2. & Knowledge & Written test & $\begin{array}{l}\text { written tests and } \\
\text { assessment sheets }\end{array}$ \\
\hline 3. & Skills & $\begin{array}{l}\text { Observation and } \\
\text { performance } \\
\text { appraisal }\end{array}$ & $\begin{array}{l}\text { Presentation } \\
\text { Observation Sheet and } \\
\text { Practice Assessment } \\
\text { Sheet }\end{array}$ \\
\hline
\end{tabular}

\section{B. Data Based Industry Assesment KKNI}

The development model of instrument development needs to be supported with the real conditions that the world needs. Febriana conducted competency mapping on the D3 program conducted with pre-survey activities, which included observation, interviews, and questionnaire dissemination. Based on the results of these activities identified a number of competencies needed world of work [11].

The results of the analysis of the questionnaire responded by the speakers, then obtained the competence elements needed by the world of work that refers to the work applicable in the world. The identification, then compiled in the matrix of competence needs of the world of work. Broadly speaking, this competency consists of 2 main competencies, namely: (1) technical skills and (2) employability skills.

Technical skills are competencies in a particular field of work including the mastery of knowledge and skills, and generally related to the ability to perform routine tasks or tasks. Employability skills or employability skills is the ability to manage attitudes and work behaviors that include attitude aspects and the introduction of the nature of the work related.

\section{Identification of Componen Technical and Employaility Skills on Based KKNI}

Preliminary research results about industry assessment of Student Competition Based KKNI obtained data as follows:
TABLE III THE INDUSTRY ASSESMENT OF THE INSTRUMENTS BASED KKNI

\begin{tabular}{|c|c|c|}
\hline Assessment of Industry & Iechnical Skills $^{\text {The }}$ & Employzabing SGills \\
\hline \multirow[t]{2}{*}{ WorkKnowledge } & Knowledge of the fald of wodk & \\
\hline & $\begin{array}{l}\text { Abilify to analyze tasks being worked } \\
\text { on }\end{array}$ & \\
\hline \multirow[t]{6}{*}{ Worling Capability } & Workprepration & \\
\hline & 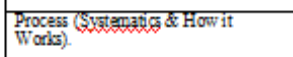 & \\
\hline & Results and prasentition & \\
\hline & 11ime & \\
\hline & $\begin{array}{l}\text { Managerial ability in rowfine task } \\
\text { completion }\end{array}$ & \\
\hline & $\begin{array}{l}\text { Ablify touse IT according to fieldof } \\
\text { work. }\end{array}$ & \\
\hline \multirow[t]{5}{*}{ Managenal ability } & & \begin{tabular}{|l} 
Aspects of Productivity \\
\end{tabular} \\
\hline & & $\begin{array}{l}\text { Aspects ofcooperation } \\
\text { (Teanwork) }\end{array}$ \\
\hline & & Aspects of Marale \\
\hline & & Creativity \\
\hline & & Solution to problem \\
\hline \multirow[t]{6}{*}{ Atritude of work } & & Attinude in Work \\
\hline & & $\begin{array}{l}\text { Security and safety (work } \\
\text { salfery) }\end{array}$ \\
\hline & & Honesty \\
\hline & & Discpilme \\
\hline & & Ledership \\
\hline & & Conmumication \\
\hline
\end{tabular}

Identification of Component of Technical Assessment and Employability Skills Based on KKNI (Indonesia National Qualification Framework)

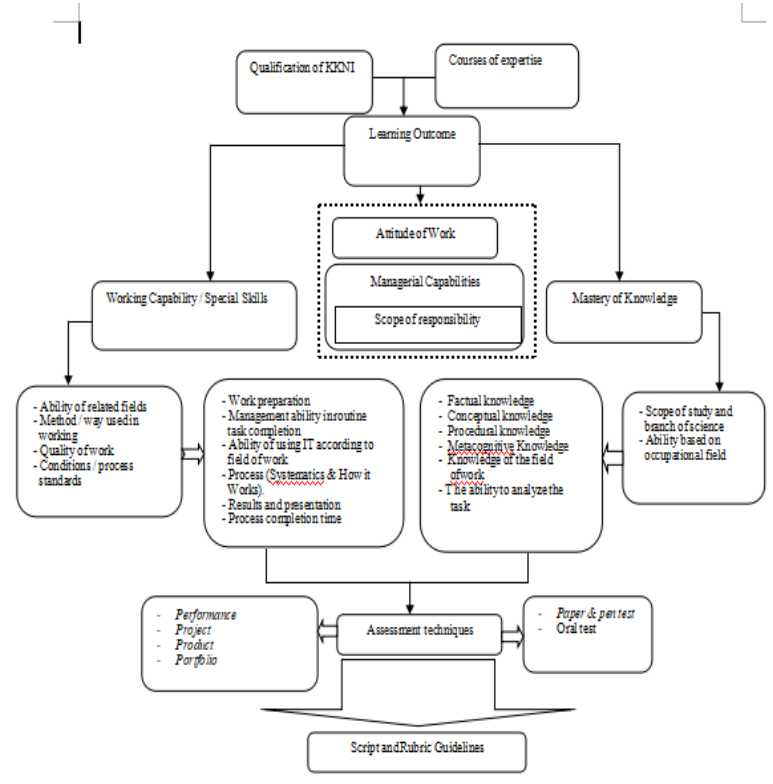

Fig. 1. Identification of component assessment of technical and employability skills based on KKNI

A summary of the results of the validator's assessment of the conceptual component model identification can be seen in the Table below: 
TABLE IV. MODEL COMPONENT VALIDATION RESUltS

\begin{tabular}{|c|c|c|c|c|}
\hline No & The assessed component & \multicolumn{3}{|c|}{\begin{tabular}{l|l|l|}
\multicolumn{3}{|c|}{ Validatar } \\
\begin{tabular}{c|c|c|} 
\\
\end{tabular} & 2 & 3 \\
\end{tabular}} \\
\hline \multicolumn{5}{|c|}{ I. Supporting theories } \\
\hline & 1.Development of assessment instruments in accordance with suppoting conceptual theories & 4 & 3 & 4 \\
\hline & $\begin{array}{l}\text { 2. The development of assessment instruments includes all learning achievements in KKNI } \\
\text { (attitudes, managerial skills, mastery of knowledge, and wouk ability). }\end{array}$ & 4 & 4 & 4 \\
\hline \multicolumn{5}{|c|}{ II. Principles of Development } \\
\hline & 1.Development procedures are clearly described & 3 & & 4 \\
\hline & 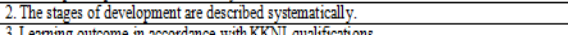 & 4 & $\frac{2}{3}$ & 3 \\
\hline & 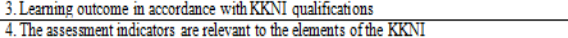 & $\frac{4}{4}$ & $\frac{3}{3}$ & $\frac{4}{4}$ \\
\hline & 5. The development goals are clearly described & 3 & $\frac{3}{2}$ & $\frac{7}{3}$ \\
\hline \multicolumn{5}{|c|}{ III. General Asses ment of Develoopment of Assessment Component Model Components } \\
\hline & Information: & B & B & B \\
\hline & $\begin{array}{l}\text { A Can be used without revision } \\
\text { B. Can be used with small revisions } \\
\text { C. Can be used with major revisions } \\
\text { D, Notyet usable }\end{array}$ & & & \\
\hline & Overall value & & 23,7 & \\
\hline & Average value & 3,4 & & \\
\hline
\end{tabular}

\section{Field Test Result}

Field trials conducted with subject lecturer field productive field. The results of the analysis on the field trials as follows:

TABLE V. FIELD EVALUATION

\begin{tabular}{|c|c|c|c|}
\hline Aspect & Dascrption Aspect & Score & Average \\
\hline \multirow[t]{5}{*}{ Validity } & $\begin{array}{l}\text { Assessment with this } \\
\text { instrument can achise } \\
\text { competence according to KKNI }\end{array}$ & og & 3,43 \\
\hline & $\begin{array}{l}\text { Parameters andelements in the } \\
\text { instrument in accordance with } \\
\text { KKNI description. }\end{array}$ & 67 & 3,35 \\
\hline & $\begin{array}{l}\text { The instrument has met the } \\
\text { leaning achieventent based on } \\
\mathrm{KKN} \text {. }\end{array}$ & 66 & 3,30 \\
\hline & $\begin{array}{l}\text { The mdicatos developed are } \\
\text { relevant leming achievenents } \\
\text { in KKNI }\end{array}$ & 04 & 5,20 \\
\hline & $\begin{array}{l}\text { The results of the ass essment } \\
\text { with this instrument can be } \\
\text { accomnted }\end{array}$ & 68 & 3,40 \\
\hline \multirow[t]{2}{*}{ Reliability } & $\begin{array}{l}\text { If used repeatedlythis } \\
\text { assessment instrument can } \\
\text { provide consistent result }\end{array}$ & 66 & 3,30 \\
\hline & $\begin{array}{l}\text { Indicalors in this asssament } \\
\text { instrument can provide } \\
\text { consistent results if ifsed by } \\
\text { other areas of espertise. }\end{array}$ & 71 & 3,52 \\
\hline \multirow[t]{3}{*}{ Objectivity } & $\begin{array}{l}\text { The use of this assessment } \\
\text { instrument makes it easier for } \\
\text { lecturers toprovide } \\
\text { assessments to students }\end{array}$ & 67 & 3,35 \\
\hline & $\begin{array}{l}\text { The use of these assessment } \\
\text { instruments is objective }\end{array}$ & 01 & 3,53 \\
\hline & $\begin{array}{l}\text { The use of these assessment } \\
\text { instruments can train student } \\
\text { discipline. }\end{array}$ & 69 & 3,45 \\
\hline \multirow[t]{4}{*}{ Practicality } & $\begin{array}{l}\text { Use of this as sessment } \\
\text { instrument can assist students } \\
\text { in achieving learning } \\
\text { achievement }\end{array}$ & 67 & 3,35 \\
\hline & $\begin{array}{l}\text { The assesment indicatoss in } \\
\text { this instrument are highly } \\
\text { measurable }\end{array}$ & $6 ?$ & 3,35 \\
\hline & $\begin{array}{l}\text { Grung score/ scose in this } \\
\text { instrument is very easy }\end{array}$ & 75 & 3,05 \\
\hline & $\begin{array}{l}\text { This research 1nstrungent } 15 \\
\text { easy to use }\end{array}$ & O? & 3,55 \\
\hline \multicolumn{4}{|l|}{ TotalScore } \\
\hline Average & & & 3,35 \\
\hline
\end{tabular}

Based on the above calculation results, the overall average score achieved in the good category that is with points 3.38. This suggests that these assessment instruments are effective for use.

\section{CONCLUSION}

In an effort to develop an assessment instrument on productive subjects based on KKNI, it is necessary to have several steps to be done to match the research objectives of producing an integrated assessment instrument with parameters and elements in the description of KKNI. From the interim results obtained in half the time of the study, it can be concluded that the learning achievement indicators developed in accordance with the needs of the industrial world and the world of work as stakeholders.

The provisional results obtained show that the process of developing this instrument is through research and development process by generating conceptual model, hypothetical model and producing instrument of assessment based on KKNI.

\section{REFERENCES}

[1] L. Efison Munjanganja. International Handbook of Education for the Changing World of Work: Bridging Academic and Vocational Learning. UNESCO-UNEVOC International Centre. 2013

[2] Peraturan Presiden No.8 Tahun 2012, Tentang KKNI

[3] Yorke, M. \& Knight, P. Embedding employability into the curriculum.Learning and Employability Series One. Higher Education Academy: New York. 2006

[4] Departement of Education, Science and Training (DEST). Employability Skills for the Future. Australia: Commonwealth. 2002

[5] Learning and Skills Improvement Service (LSIS). Pre-redundancy Employability Toolkit. http://www.moveon.org.uk/downloadsFile/downloads3157/23_LSIS_RedunHbook.pdf. 2010.

[6] LOMA,s Competency Dictionary, (1988) in Hitt, Michael A., R. Edward Freeman and Jeefrey S. Harrison (2006); The Blackwell Handbook of Strategic Management; Print Publication: 2006PERMENDIKBUD No.73 Tahun 2013, Penerapan KKNI Bidang Perguruan Tinggi

[7] Wagiran, W. 2008. The Importance of Developing Soft Skills in Preparing Vocational High School Graduates. (online), (http://www.voctech.bn, access on 19 Agustus 2011)

[8] Muchlas, Samani.. Pendidikan kecakapan hidup: Upaya merekonstruksi pendidikan. Makalah. Disajikan dalam seminar dan lokakarya bidang peningkatan relevansi program DUE-LIKE Jurusan Pendidikan Fisika IKIP Negeri Singaraja tanggal 15-16 Agustus, di Singaraja. 2004

[9] Turner, N. K. (2014). Development of self-belief for employability in higher education: Ability, efficacy and control in context. Teaching in Higher Education, 19(6), 592-602. https://doi.org/10.1080/13562517.2014.901951

[10] Fraenkel, J.R. \& Wallen, N.E. How to Design and Evaluate Research in Education. New York: Mc.Graw Hill Pub Co. 1990Investopedia.(http://www.investopedia.com/terms/t/technicaljob-skills.asp).

[11] Febriana, Rina. Development of Competency Based Curriculum with Working World Approach on The Diploma 3 Program. Unpublished dissertation. Yogyakarta. 2014.

[12] Febriana, Rina. Development of Assessment Instrument in Subject Areas of Expertise Based on Indonesian National Qualification Framework (KKNI). Hibah Penelitian Unggulan Perguruan Tinggi. Jakarta. 2017.

[13] Kurniasih, Farida dan Setiawan, Ngadirin. 2013. Pengembangan Media Film Dokumenter Sebagai Pendukung Pembelajaran Akuntansi Perusahaan Dagang Bagi Siswa SMK Kelas X Akuntansi. Universitas Negeri Yogyakarta.Volume : 2 Halaman :29 